Article

\title{
Ficus microcarpa Bonsai "Tiger bark" Parasitized by the Root-Knot Nematode Meloidogyne javanica and the Spiral Nematode Helicotylenchus dihystera, a New Plant Host Record for Both Species
}

\author{
Duarte Santos $^{1}$ (D), Isabel Abrantes ${ }^{1}$ and Carla Maleita ${ }^{1,2, *(D)}$ \\ 1 CFE, Department of Life Sciences, University of Coimbra, Calçada Martim de Freitas, 3000456 Coimbra, \\ Portugal; duartenema@outlook.pt (D.S.); isabel.abrantes@uc.pt (I.A.) \\ 2 CIEPQPF, Department of Chemical Engineering, University of Coimbra, Rua Sílvio Lima, Pólo II-Pinhal de \\ Marrocos, 3030-790 Coimbra, Portugal \\ * Correspondence: carla.maleita@uc.pt
}

Received: 5 July 2020; Accepted: 20 August 2020; Published: 24 August 2020

\begin{abstract}
In December 2017, a Ficus microcarpa "Tiger bark" bonsai tree was acquired in a shopping center in Coimbra, Portugal, without symptoms in the leaves, but showing small atypical galls of infection caused by root-knot nematodes (RKN), Meloidogyne spp. The soil nematode community was assessed and four Tylenchida genera were detected: Helicotylenchus (94.02\%), Tylenchus s.l. (4.35\%), Tylenchorynchus s.l. (1.09\%) and Meloidogyne (0.54\%). The RKN M. javanica was identified through analysis of esterase isoenzyme phenotype (J3), PCR-RFLP of mitochondrial DNA region between COII and 16S rRNA genes and SCAR-PCR. The Helicotylenchus species was identified on the basis of female morphology that showed the body being spirally curved, with up to two turns after relation with gentle heat, a key feature of $H$. dihystera, and molecular characterization, using the D2D3 expansion region of the $28 \mathrm{~S} \mathrm{rDNA}$, which revealed a similarity of $99.99 \%$ with available sequences of the common spiral nematode $H$. dihystera. To our knowledge, $M$. javanica and $H$. dihystera are reported for the first time as parasitizing F. microcarpa. Our findings reveal that more inspections are required to detect these and other plant-parasitic nematodes, mainly with quarantine status, to prevent their spread if found.
\end{abstract}

Keywords: 28S ribosomal DNA; mitochondrial DNA region; pest interception; plant-parasitic nematodes; SCAR-PCR

\section{Introduction}

The globalization era opens up new trade routes and increases the volume and complexity of cross-border transactions of goods. The plant sector (plant products, germplasm, grafts and live plants) has been part of the general trend in increased trade. This exchange of species between distant geographical regions of the globe creates new pathways for the introduction of alien plant pests and diseases $[1,2]$.

The introduction of a non-native organism in a new environment produces unpredictable effects. A species may have low impact in its native range, but much greater impact when introduced to new areas, putting native biodiversity and local production systems at risk [1,3,4]. For instance, the introduction of the alien pinewood nematode Bursaphelenchus xylophilus in Portugal has caused huge environmental and economic losses in Portuguese pine forests, while in North America, where this nematode is native, it does not cause significant mortality to native conifers [5-7]. These problems are expected to be intensified in the future as climate change is predicted to facilitate the further spread of 
these species, since many of these new pathogens are of tropical and subtropical origins [8,9]. Recently, the tropical root knot nematode (RKN) Meloidogyne luci (Alert List of the European and Mediterranean Plant Protection Organization-EPPO) and M. enterolobii (A2 List of Pests EPPO) were detected in Portugal. Meloidogyne luci was found to be associated with potato (Solanum tuberosum) and tomato (S. lycopersicum), the ornamental plant Cordyline australis, and the weed Oxalis corniculata, whereas M. enterolobii was detected in the ornamental plants Cereus hildmannianus, Lampranthus sp., Physalis peruviana and Callistemon sp. Taking into account its aggressiveness and distribution, there is a high probability of spread in the Mediterranean region and also in Europe, becoming a potential threat to the agricultural economy $[10,11]$.

The European Commission has proposed an import ban on 35 genera of plants for planting, other than seeds, in vitro material and natural or artificially dwarfed woody plants for planting from countries outside the European Union (EU). Ficus carica, common fig, is the only species of the genus Ficus included on the list. The ban was put into effect in December 2019 and aims to reduce the probability of the introduction of harmful organisms in the EU [12]. During a survey (3 years) in the Netherlands, around $20 \%$ of samples of imported plants for planting and ornamentals from 21 countries showed quarantine nematodes and 11\% other important nematodes [13].

Ficus constitutes one of the largest genera of flowering plants (Angiosperms) that, according to the plant list version 1.1 (http://www.theplantlist.org), has 919 accepted species, being primarily found in tropical and subtropical environments throughout the world [14]. During the past few decades, plants from this genus have become quite popular as indoor house plants.

Despite the diversity of Ficus species, the research regarding plant-parasitic nematodes (PPN) has been focussed on the edible fig tree F. carica native to western Asia and introduced in the Mediterranean region. A number of PPN species have been reported as parasitizing fig trees in many countries, the most prevalent belonging to the genera Helicotylenchus (spiral nematodes), Heterodera (cyst nematodes), Meloidogyne (root-knot nematodes), Paratylenchus (pin nematodes), Pratylenchus (root lesion nematodes, RLN) and Xiphinema (dagger nematodes) [15-24]. Of these, the most common are the RKN species $M$. arenaria, $M$. hapla, $M$. hispanica, $M$. incognita and $M$. javanica, economically important species that directly target plant roots and prevent water and nutrient uptake, resulting in growth or even plant death in extreme cases, and the species Heterodera fici, a worldwide parasite of ornamental and cultivated Ficus species [24,25].

Concerning Ficus bonsai, besides F. carica, other species, such as F. benghalensis, F. macrophylla, F. microcarpa, F. retusa and F. rubiginosa, have been considered suitable for bonsai plants, but records of PPN on them are few and scarce. Some bonsai plants with nematode infections have been intercepted in Europe and other parts of the world [13,26,27].

The species F. microcarpa, the Indian laurel tree, sometimes confused with F. nitida and F. retusa, is widely distributed as an ornamental plant either outdoors or indoors and is known for its pharmacological properties: antioxidant, antibacterial, anticancer, anti-diabetic, anti-diarrhoeal, anti-inflammatory, anti-asthmatic, hepatoprotective and hypolipidemic [28]. This Ficus species is a host of many pests, including the Cuban laurel thrips (Gynaikothrips ficorum), the Ficus leaf-rolling psyllid (Trioza brevigenae), and the Ficus whitefly (Singhiella simplex), among others [29]. The PPN found associated with F. microcarpa include the genera Helicotylenchus, Meloidogyne, Pratylenchus, Tylenchorynchus and Xiphinema, and the RKN M. enterolobii species have been intercepted in bonsais or plants for planting imported from China or Egypt [27].

The aims of the present study were to find the nematode diversity associated to F. mircrocarpa bonsai plant, to characterize/identify the RKN, Meloidogyne sp., and the spiral nematode, Helicotylenchus sp., parasitizing F. microcarpa (Figure 1a) and to enlarge the knowledge on the phytoparasitic nematodes of this Ficus species. 


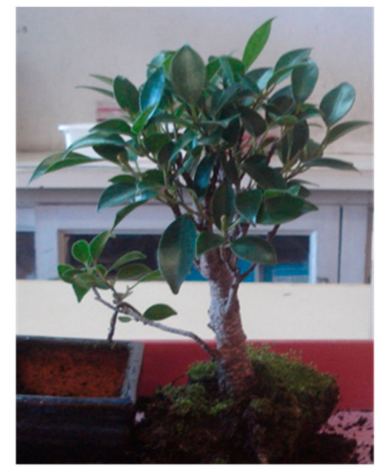

(a)

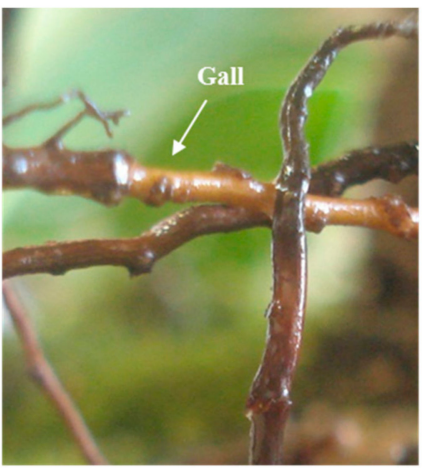

(b)

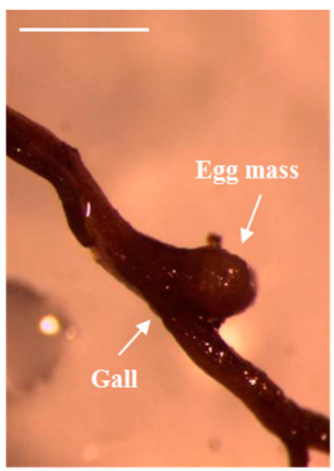

(c)

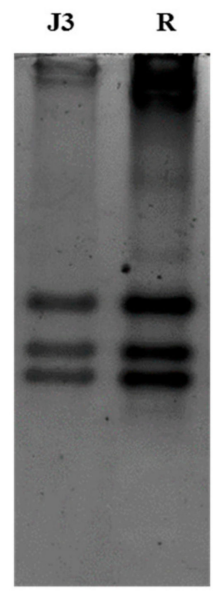

(d)

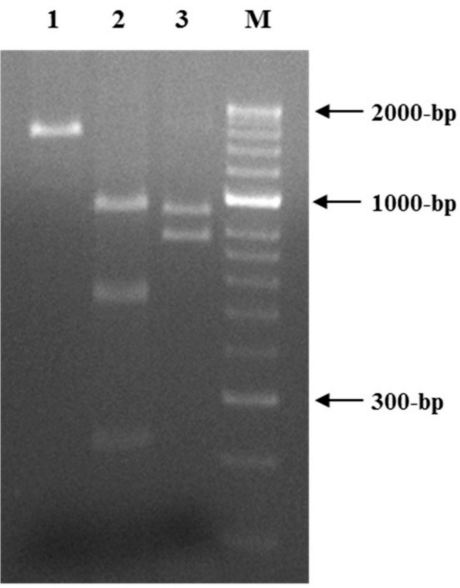

(e)

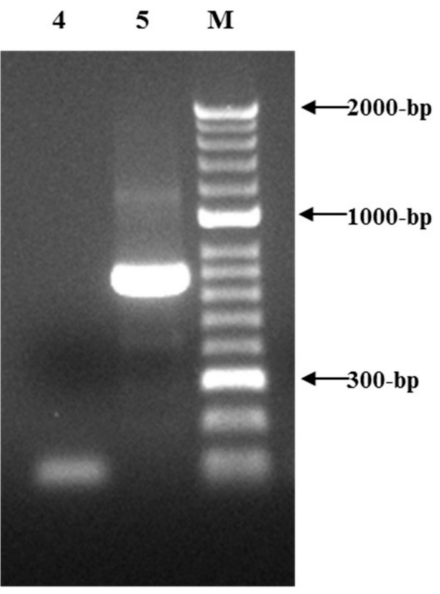

(f)

Figure 1. Meloidogyne javanica parasitizing Ficus microcarpa. (a) F. microcarpa. (b,c) F. microcarpa infected roots. (d) Polyacrylamide gel stained for esterase activity. J3, M. javanica (F. microcarpa isolate); R, $M$. javanica (reference isolate). (e) HinfI (1), AluI (2) and DraIII (3) digestion patterns of the approximately 1800-bp amplification products from $M$. javanica, using C2F3 and MRH106 primers. M, DNA marker (HyperLadder II; Bioline). (f) DNA amplification product using Fjav and Rjav primers. 4, Negative control; 5, M. javanica; M, DNA marker (HyperLadder II; Bioline). Scale bar: $1 \mathrm{~mm}$.

\section{Results and Discussion}

Meloidogyne females plus egg masses (Figure 1b,c) and Helicotylenchus specimens (Figure 2a) were detected in fresh and stained roots. Although Helicotylenchus spp. are classified as ectoparasites or semi-endoparasites, they can penetrate the roots and were already found completely embedded in the cortical tissue of the root system of sycamore (Platanus occidentalis) [30]. The galls were small and hard, mainly in woody roots (Figure $1 b, c$ ), which is common in woody perennial plants. The PPN detected in the soil sample (130 g) of F. microcarpa bonsai belonged to four genera: Helicotylenchus $(94.02 \%)$, Tylenchus s.l. (4.35\%), Tylenchorynchus s.l. (1.09\%) and Meloidogyne J2 (0.54\%). The spiral nematode Helicotylenchus was the most prevalent PPN, detected in very high numbers, with approximately 3000 nematodes.

For the RKN isolate, the biochemical characterization resulted in three bands of esterase (relative mobility \%: $0.38 ; 0.45 ; 0.49$ ), which is the characteristic phenotype exhibited by $M$. javanica (J3) isolates (Figure 1d). The mtDNA COII and 16S rRNA genes region amplified with the primer set C2F3/MRH106 yielded a single fragment of $1800 \mathrm{bp}$. When the amplified product was digested with the restriction enzyme HinfI, no digestion occurred. AluI and DraIII generated three fragments of approximately 1000,580 , and $240 \mathrm{bp}$ and two fragments of approximately 1000 and $800 \mathrm{bp}$, which is in accordance with other results for this species [31] (Figure 1e). Additionally, molecular characterization of the RKN 
species with the species-specific primers Fjav and Rjav produced a fragment size of $600 \mathrm{bp}$, as expected, thus confirming the presence of $M$. javanica (Figure 1f).

This RKN species is known to parasitize F. carica and is one of the most widely distributed species and the second highest in economic importance after M. incognita [22,23,32]. Meloidogyne javanica was first reported from Portugal on potato in Azores [33]. Since then, it has been found on several economically important crops, including Humulus lupulus, Musa sp., Phaseolus vulgaris, Prunus persica, S. lycopersicum and S. tuberosum, ornamental plants, such as Cordyline australis and Dianthus plumarius, as well as many other dicots [11,34-40].

Helicotylenchus females were spirally curved, with up to two turns after relation with gentle heat, a key feature of $H$. dihystera (Figure $2 b$ ), the tail dorsally convex-conoid to a narrow terminus with a slight projection (Figure 2d) and lateral field with four non-areolated incisures (Figure 2e). Males were not found [41]. Amplification of the D2D3 expansion region of the 28S rDNA gene resulted in a product of ca. $750 \mathrm{bp}$ (Figure 3). Sequences (744 bp) were submitted to the GenBank database with accession numbers MT277384, MT277385 and MT277386. The three sequences of the Helicotylenchus sp. from Ficus microcarpa (Fm) were compared and nine nucleotide changes at positions 57, 77, 98, $189,537,541,546,548$ and 572 in alignment were identified. The comparison of this region with the Helicotylenchus sequences available in the GenBank database revealed a similarity of $99.99 \%$ with H. dihystera. Phylogenetic analysis from the alignment of Fm Helicotylenchus $28 \mathrm{~S}$ rDNA sequences with available sequences of similar Helicotylenchus spp. [41] revealed that this isolate and all listed $H$. dihystera sequences appeared together in a well-separated clade with $100 \%$ bootstrap support (Figure 4), confirming the morphological identification. Considering a common start and end point to Helicotylenchus spp. (560 bp), the Fm sequences differed in several positions from at least one $H$. dihystera sequences included in the analysis; however, only three $(4,493$ and 519) position changes were completely distinct from $H$. dihystera sequences (Figure S1). Fm $H$. dihystera sequences had divergences ranging from 0.2 to $2.2 \%$ when compared with $H$. dihystera sequences and 3.7 to $6.5 \%$ to the other Helicotylenchus species (Table S1).
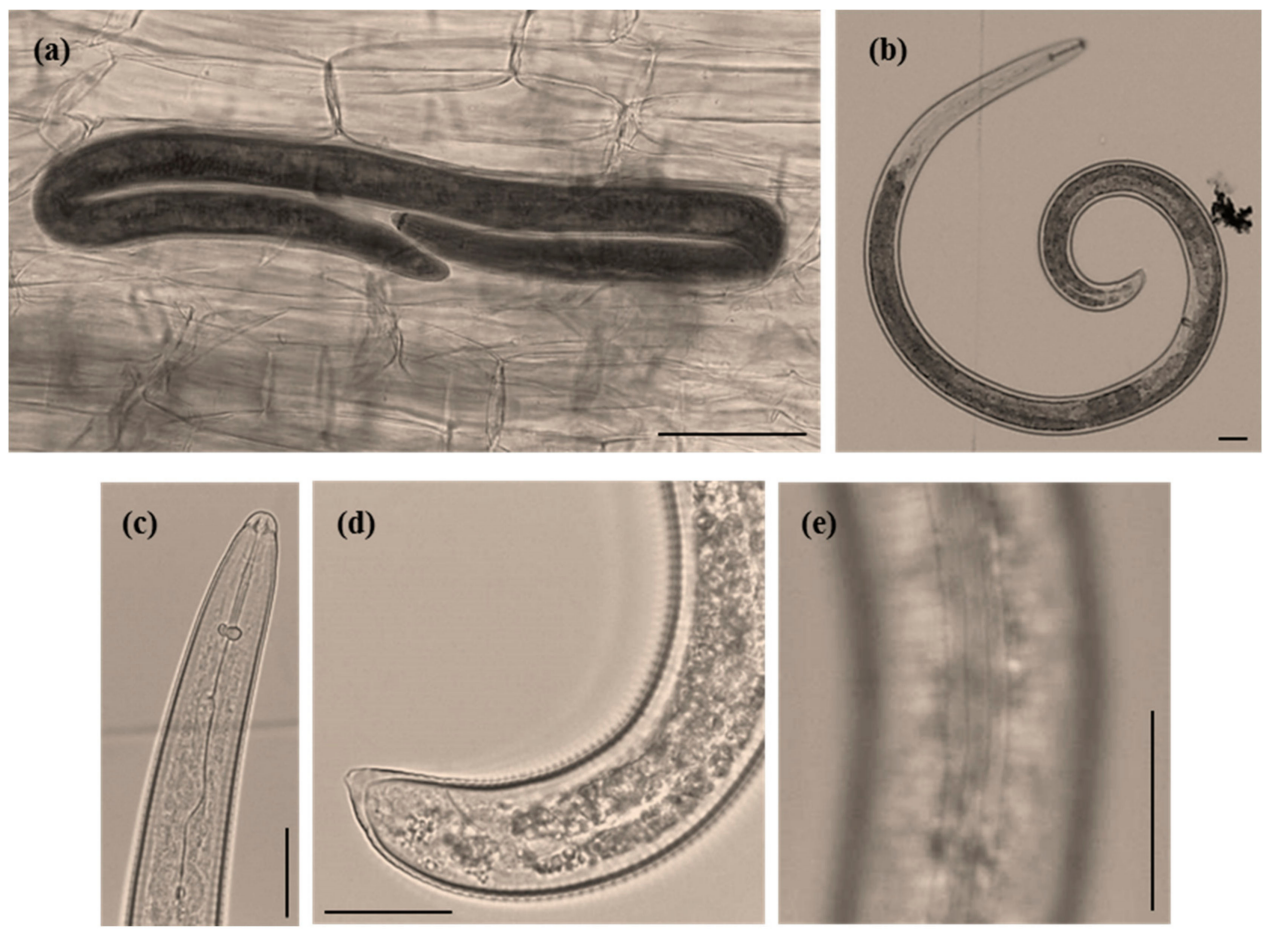

Figure 2. Helicotylenchus dihystera (females) light microscope photographs. (a) Infected Ficus microcarpa root. (b) Whole specimen. (c) Anterior region in lateral view. (d) Posterior region in lateral view. (e) Lateral field with four lateral lines. Scale bars: $20 \mu \mathrm{m}(\mathbf{a}-\mathbf{d})$, and $50 \mu \mathrm{m}(\mathbf{e})$. 


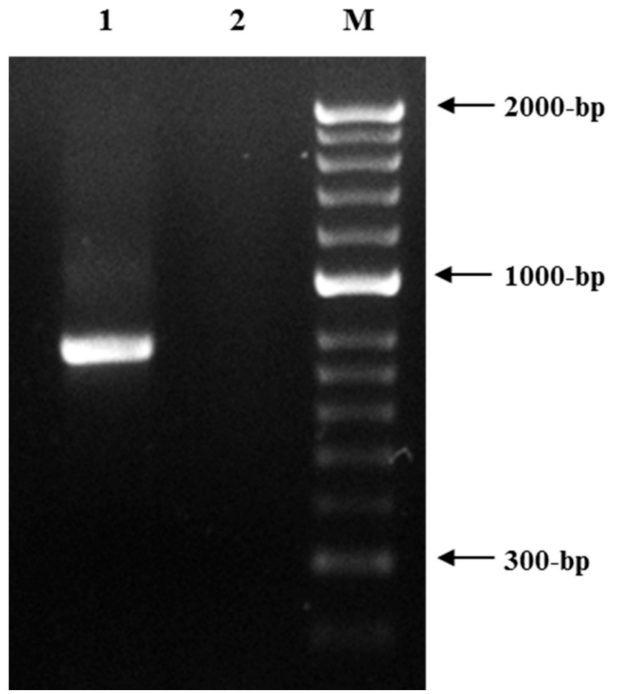

Figure 3. DNA amplification product obtained from Helicotylenchus dihystera isolate identified on Ficus microcarpa to the D2D3 expansion region of the $28 \mathrm{~S}$ rDNA gene (1). 2, negative control. M, DNA marker (HyperLadder II; Bioline).

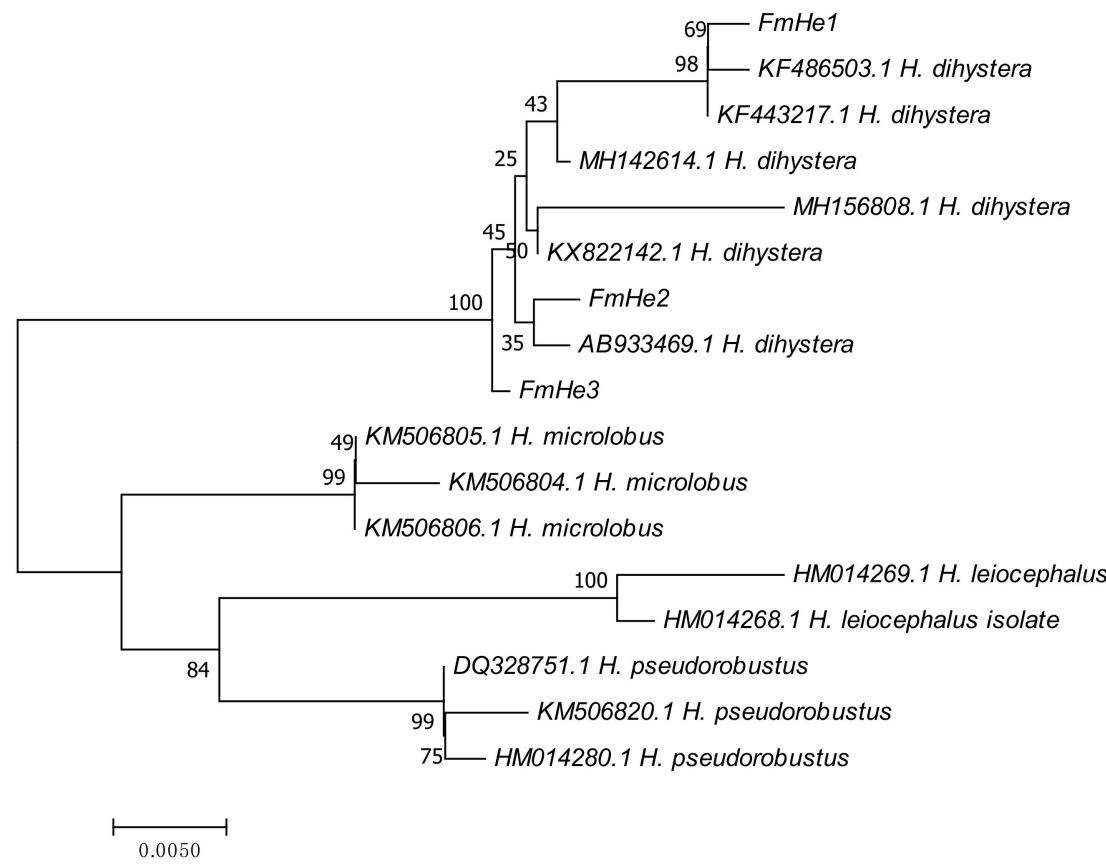

Figure 4. Neighbor-joining tree based on analysis of alignment of D2D3 expansion region of the 28S rDNA gene sequences of the Helicotylenchus dihystera isolate identified on Ficus microcarpa (FmHe) with available sequences of close Helicotylenchus spp. (H. leiocephalus, H. microlobus and H. pseudorobustus) [41]. The percentage of replicate trees in which the associated Helicotylenchus spp. clustered together in the bootstrap test (1000 replicates) is shown next to the branches. Evolutionary distances were computed using the maximum composite likelihood method and all positions containing gaps and missing data were eliminated.

Although $H$. dihystera is considered as a polyphagous species with a wide distribution, reports on its pathogenicity are very few, and it is rarely recognized as an economically important PPN [30,42-44], even when high population densities are found. This is the first report of $H$. dihystera infecting F. microcarpa; however, it has been associated with F. benjamina, F. carica, F. elastica, F. formosana and 
F. retusa [21,26,44-47]. In Portugal, H. dihystera was reported as being associated with Begonia sp., Colocasia esculenta, Cactus sp., Mentha sp., Musa sp., Pelargonium sp., Polygonaceae, beans, maize and tomato $[45,48-50]$.

Although no specific quarantine measures are being implemented against $M$. javanica or H. dihystera, preventive measures are particularly important to decrease the risk of spread into a region where they do not exist. Once nematodes are established in the soil, their eradication is very difficult. Thus, the use and transportation of clean, healthy, nematode-free planting material is a prerequisite for limiting the spread of nematodes. Plant parts liable to carrying PPN in trade/transport can be bulbs/tubers/corms/rhizomes, growing medium accompanying plants, roots and micropropagated plants. During routine inspections, the detection of nematode infections can be easily overlooked or misdiagnosed, as low to moderate populations of nematodes may cause no visible aboveground symptoms, making it harder to diagnose them [51,52]. Furthermore, above-ground symptoms are non-specific and usually involve stunting, lack of vigour, leaf nutritional deficiencies and temporary wilting in periods of water stress and high temperatures. The examination of roots can reveal the presence of galls that are specific symptoms associated with the occurrence of Meloidogyne spp., but the symptoms caused by Helicotylenchus spp., when present, can be confused with the damage associated with poor nutrition or injury caused by pathogens that attack the root system (other nematodes, bacteria, fungi and/or virus).

To our knowledge, $M$. javanica and H. dihystera are here reported for the first time as parasitizing F. microcarpa. Although both PPN species are common and widely distributed, our findings emphasize the importance of inspections by governmental authorities to find out whether imported material is free of PPN. If plants are grown in infested soil and then commercialized, it increases the probability of PPN dissemination to new regions and/or other suitable hosts with potential impact on economically important crops.

\section{Materials and Methods}

In December 2017, a F. microcarpa "Tiger bark" bonsai tree with a phytosanitary certificate was acquired by the first author in a shopping center in Coimbra, Portugal, showing small galls in the protruding roots, which aroused our attention, but without symptoms in the leaves (Figure 1a,b). Consequently, a few roots and a soil sample of $130 \mathrm{~g}$ were collected from the pot. Roots were observed directly and stained with acid fuchsin to detect nematode-infected plant tissues [53]. Nematodes were extracted from the soil, according to the Tray Method [54], followed by microscopic examination of nematode diversity and the genera identified and quantified.

\subsection{Root Knot Nematode Characterization/Identification}

Egg masses from F. microcarpa galled roots were propagated on tomato, Solanum lycopersicum, cv. Coração-de-Boi, in a growth chamber. After two months, the infected tomato roots were gently rinsed with tap water and 5 young egg-laying females were, individually and randomly, handpicked with their respective egg masses to glass blocks with $\mathrm{NaCl} 0.9 \%$ to obtain pure cultures. Individual young egg-laying females were characterised biochemically by electrophoretic analysis of esterases. Esterase electrophoresis was performed using polyacrylamide gels following the methodology described by Pais and Abrantes [55]. The individual females were transferred to micro-haematocrit tubes containing $5 \mu \mathrm{L}$ of extraction buffer ( $20 \%$ sucrose and $1 \%$ Triton X-100), macerated and stored at $-20^{\circ} \mathrm{C}$. Before electrophoresis, the samples were centrifuged at $8905 \mathrm{~g}$, at $-5^{\circ} \mathrm{C}$ for $15 \mathrm{~min}$. Electrophoresis was performed at $6 \mathrm{~mA} / g e l$ during the first $15 \mathrm{~min}$ and then at $20 \mathrm{~mA} / \mathrm{gel}$ for about $45 \mathrm{~min}$ using the Mini-Protean Tetra System (Bio-Rad Laboratories, Hercules, CA, USA). The gels were stained for esterase activity with the substrate $\alpha$-naphthyl acetate, in the dark at $37^{\circ} \mathrm{C}$. Protein extract from five females of $M$. javanica was included in each gel as a reference. A pure culture (designated as Fm) of RKN was established by inoculating the 5 individual egg masses onto tomato to obtain a sufficient number of second-stage juveniles for molecular characterization. Electrophoretic analysis of esterases 
was repeated after two months to confirm the biochemical identification and the relative movement of each band calculated taking as reference the buffer front (Relative mobility, Rm\%).

Biochemical identification was further confirmed by PCR-RFLP of mtDNA region between COII and 16S rRNA genes with C2F3 and MRH106 primers, and by SCAR-PCR with the species-specific primers Fjav and Rjav, using a pellet of second-stage juveniles (J2) obtained from egg masses of the pure isolate [31,56]. Briefly, for mtDNA region amplification, each PCR contained 1X PCR buffer, 1.8 $\mathrm{mM} \mathrm{MgCl} 2,0.2 \mathrm{mM}$ dNTPs, $0.2 \mu \mathrm{M}$ of each primer, $2.5 \mathrm{U}$ Taq DNA polymerase (Bioline), and $50 \mathrm{ng}$ DNA. Amplification was conducted using the following conditions: initial denaturation at $94{ }^{\circ} \mathrm{C}$ for 4 min, followed by 40 cycles of $94{ }^{\circ} \mathrm{C}$ for $30 \mathrm{~s}, 60{ }^{\circ} \mathrm{C}$ for $30 \mathrm{~s}$, and $72{ }^{\circ} \mathrm{C}$ for $60 \mathrm{~s}$, and a final extension for $10 \mathrm{~min}$ at $72{ }^{\circ} \mathrm{C}$. After amplification, the PCR product was digested separately with $5 \mathrm{U} H$ Hinf, AluI and DraIII. For SCAR-PCR, the PCR reactions were the same as for the mtDNA region, except the primers $\left(0.3 \mu \mathrm{M}\right.$ of each primer) and the amplification conditions ( 35 cycles of denaturation at $94{ }^{\circ} \mathrm{C}$ for $30 \mathrm{~s}$, annealing at $52{ }^{\circ} \mathrm{C}$ for $30 \mathrm{~s}$ and extension at $72{ }^{\circ} \mathrm{C}$ for $1 \mathrm{~min}$ ).

\subsection{Spiral Nematode Characterization/Identification}

Helicotylenchus specimens from soil and roots were propagated on the same tomato cultivar, in a growth chamber. Two/three months after inoculation, with approximately 3000 specimens, nematodes were extracted from roots/soil, according to the generalist Tray Method [54] and used to Helicotylenchus species characterization/identification and isolate maintenance, respectively. The characterization and identification of the Helicotylenchus species was based on the morphological characters of 10 females (body shape after relaxed with gentle heat and number of incisures) and ribosomal DNA (rDNA) sequencing.

DNA was extracted and purified from 20 spiral nematodes, extracted from tomato roots, using the DNeasy Blood and Tissue kit (QIAGEN, Valencia, CA, USA), according to the manufacturer's instructions, and the D2D3 expansion region of the 28S rDNA gene was amplified using D2A (5' -ACA AGT ACC GTG AGG GAA AGT TG-3') and D3B (5'-TCG GAA GGA ACC AGC TAC TA-3') primers [57]. The PCR products were analysed on $1 \%$ agarose gel stained with GreenSafe (Nzytech), purified from the gel with the MiniElute Gel Extraction kit (QIAGEN, Valencia, CA, USA), quantified using the NanoDrop 2000C spectrophotometer (Thermo Scientific), cloned and sequenced. Sequences were compared with available close Helicotylenchus spp. sequences in GenBank [41]. Sequences were aligned using CLUSTALW multiple alignment in BIOEDIT software [58]. The evolutionary history was inferred using the neighbor-joining (NJ) and maximum likelihood (ML) methods in MEGA 7, as described in Santos et al. [10,59].

Supplementary Materials: The following materials are available online at http://www.mdpi.com/2223-7747/ 9/9/1085/s1, Figure S1: Multiple sequence alignment of Fm Helicotylenchus (FmHe1, FmHe2 and FmHe3) and available close Helicotylenchus spp. (H. dihystera-AB933469.1, MH156808.1, MH142614.1, KX822142.1, KF486503.1, KF443217.1; H. pseudorobustus-KM506820.1, HM014280.1, DQ328751.1; H. microlobus-KM506806.1, KM506805.1, KM506804.1; H. leiocephalus-HM014269.1, HM014268.1) sequences of D2D3 expansion region of the 28S rDNA gene (560 bp), Table S1: Pairwise sequence divergences between Fm Helicotylenchus and available close Helicotylenchus spp. sequences in GenBank of D2D3 expansion region of the 28S rDNA gene using MEGA7.

Author Contributions: Conceptualization, D.S. and C.M.; methodology, D.S., I.A. and C.M.; software, C.M.; validation, D.S., I.A. and C.M.; formal analysis, I.A.; investigation, D.S. and C.M.; resources, I.A. and C.M.; data curation, D.S. and C.M.; writing-original draft preparation, D.S.; writing-review and editing, I.A. and C.M.; visualization, D.S., I.A. and C.M.; supervision, I.A. and C.M.; project administration, I.A. and C.M.; funding acquisition, I.A. and C.M. All authors have read and agreed to the published version of the manuscript.

Funding: This research was supported by CFE, Department of Life Sciences, UC, and CIEPQPF, Department of Chemical Engineering, UC, and FEDER funds through the Portugal 2020 (PT 2020) "Programa Operacional Factores de Competitividade 2020" (COMPETE 2020) and by “Fundação para a Ciência e a Tecnologia" (FCT, Portugal), under contracts UIDB/04004/2020, UIDB/00102/2020, POCI-01-0145-FEDER-031946 (Ref. PTDC/ASP-PLA/31946/2017), POCI-01-0145-FEDER-029392 (Ref. PTDC/ASP-PLA/29392/2017), Project ReNATURE-Valorization of the Natural Endogenous Resources of the Centro Region (Centro2020, Centro-01-0145-FEDER-000007) and by "Instituto do Ambiente, Tecnologia e Vida". Duarte Santos is funded by a doctoral Fellowship financed by FCT (SFRH/BD/146196/2019). 
Conflicts of Interest: The authors declare no conflict of interest. The funders had no role in the design of the study; in the collection, analyses, or interpretation of data; in the writing of the manuscript, or in the decision to publish the results.

\section{References}

1. Eschen, R.; Roques, A.; Santini, A. Taxonomic dissimilarity in patterns of interception and establishment of alien arthropods, nematodes and pathogens affecting woody plants in Europe. Divers. Distrib. 2015, 21, 36-45. [CrossRef]

2. Roques, A.; Blackburn, M.A.T.M.; David, R.; Garnas, J.; Pys, P.; Wingfield, M.J.; Liebhold, A.M.; Duncan, R.P. Temporal and interspecific variation in rates of spread for insect species invading Europe during the last 200 years. Biol. Invasions 2016, 18, 907-920. [CrossRef]

3. Vovlas, N.; Trisciuzzi, N.; Troccoli, A.; De Luca, F.; Cantalapiedra-Navarrete, C.; Castillo, P. Integrative diagnosis and parasitic habits of Cryphodera brinkmani a non-cyst forming heteroderid nematode intercepted on Japanese white pine bonsai trees imported into Italy. Eur. J. Plant Pathol. 2013, 135, 717-726. [CrossRef]

4. Blackburn, T.M.; Essl, F.; Evans, T.; Hulme, P.E.; Jeschke, J.M.; Kühn, I.; Kumschick, S.; Marková, Z.; Mrugała, A.; Nentwig, W.; et al. A unified classification of alien species based on the magnitude of their environmental impacts. PLoS Biol. 2014, 12, e1001850. [CrossRef]

5. IFN6. $6^{\circ}$ Inventário Florestal Nacional. Instituto da Conservação da Natureza e das Florestas. Lisboa, Portugal. Available online: http://www2.icnf.pt/portal/florestas/ifn/ifn6 (accessed on 2 July 2020).

6. De la Fuente, B.; Beck, P.S.A. Invasive species may disrupt protected area networks: Insights from the pine wood nematode spread in Portugal. Forests 2018, 9, 282. [CrossRef]

7. EPPO. Bursaphelenchus xylophilus. EPPO Datasheets on Pests Recommended for Regulation; EPPO Global Database: Paris, France. Available online: https://gd.eppo.int (accessed on 2 July 2020).

8. Huang, D.; Haack, R.A.; Zhang, R. Does global warming increase establishment rates of invasive alien species? A centurial time series analysis. PLoS ONE 2011, 6, e24733. [CrossRef]

9. Fey, S.B.; Herren, C.M. Temperature-mediated biotic interactions influence enemy release of nonnative species in warming environments. Ecology 2014, 95, 2246-2256. [CrossRef]

10. Santos, D.; Abrantes, I.; Maleita, C. The quarantine root knot nematode Meloidogyne enterolobii-A potential threat to Portugal and Europe. Plant Pathol. 2019, 68, 1607-1615. [CrossRef]

11. Santos, D.; Correia, A.; Abrantes, I.; Maleita, C. New hosts and records in Portugal for the root-knot nematode Meloidogyne luci. J. Nematol. 2019, 51, e2019-03. [CrossRef]

12. European Commission. Commission implementing regulation (EU) 2018/2019. ANNEX I-List of High Risk Plants, Plant Products and Other Objects; European Commission: Brussels, Belgium. Available online: http://data.europa.eu/eli/reg_impl/2018/2019/oj (accessed on 20 May 2020).

13. Anthoine, G.; Niere, B.; den Nijs, L.; Prior, T.; Pylypenco, L.; Viaene, N. Nematode interceptions in international trade of plants for planting. J. Nematol. 2014, 46, 134-135.

14. Harrison, R.D. Figs and the diversity of tropical rainforests. BioScience 2005, 55, 1053-1064. [CrossRef]

15. McSorley, R. Plant Parasitic Nematodes Associated with Tropical and Subtropical Fruits; Technical Bulletin no. 823; Florida Agricultural Experiment Station: Gainesville, FL, USA, 1981; Volume 823, pp. 1-49.

16. McSorley, R. Nematological problems in tropical and subtropical fruit tree crops. Nematropica 1992, 22, 103-116.

17. Cohn, E.; Duncan, L.W. Nematode parasites of subtropical and tropical fruit trees. In Plant Parasitic Nematodes in Subtropical and Tropical Agriculture; Luc, M., Sikora, R.A., Bridge, J., Eds.; CABI Publishing: Wallingford, UK, 1990; pp. 347-362.

18. Campos, V.P. Nematóides na cultura da figueira. Inf. Agropecu. (Belo Horizonte) 1997, 18, 33-38.

19. Krnjaic, D.; Krnjaic, S.; Bacic, J. Distribution and population density of fig cyst nematode (Heterodera fici Kirjanova) in the region of SR Yugoslavia. Zast. Bilja 1997, 48, 245-251.

20. Li, H.; Xu, J.; Shen, P.; Cheng, H. Distribution and seasonal dynamic changes of nematode parasites in fig main growing areas in Jiangsu Province. J. Nanjing Agric. Univ. 1999, 22, 38-41.

21. Abrantes, I.M.d.O.; Vieira dos Santos, M.C.; da Conceição, I.L.P.M.; Santos, M.S.N.d.A.; Vovlas, N. Root-knot and other plant-parasitic nematodes associated with fig trees in Portugal. Nematol. Mediterr. 2008, 36, 131-136. 
22. Wohlfarter, M.; Giliomee, J.H.; Venter, E.; Storey, S. A survey of the arthropod pests and plant parasitic nematodes associated with commercial figs, Ficus carica (Moraceae), in South Africa. Afr. Entomol. 2011, 19, 165-172. [CrossRef]

23. Mokbel, A. Nematodes and their associated host plants cultivated in Jazan province, southwest Saudi Arabia. Egypt. J. Exp. Biol. (Zool) 2014, 10, 35-39.

24. Fanelli, E.; Vovlas, A.; Santoro, S.; Troccoli, A.; Lucarelli, G.; Trisciuzzi, N.; De Luca, F. Integrative diagnosis, biological observations, and histopathology of the fig cyst nematode Heterodera fici Kirjanova (1954) associated with Ficus carica L. in southern Italy. ZooKeys 2019, 823, 1-19. [CrossRef]

25. Karssen, G.; Wesemael, W.M.L.; Moens, M. Root-knot nematodes. In Plant Nematology; Perry, R.N., Moens, M., Eds.; CABI Publishing: Wallingford, UK, 2013; pp. 73-108.

26. Quénéhervé, P.; Topart, P.; Poliakoff, F. Interception of nematodes on imported bonsai in Martinique. Nematropica 1998, 28, 101-105.

27. EPPO. Study on the Risk of Imports of Plants for Planting; EPPO Technical Document; EPPO Global Database: Paris, France, 2012; Volume 1061.

28. Chan, E.W.C.; Tangah, J.; Inoue, T.; Kainuma, M.; Baba, K.; Oshiro, N.; Kezuka, M.; Kimura, N. Botany, uses, chemistry and pharmacology of Ficus microcarpa: A short review. Syst. Rev. Pharm. 2017, 8, 103-111. [CrossRef]

29. Hodel, D.R. New pests of landscape Ficus in California. Calif. Assoc. Pest Control Adv. (CAPCA) 2017, 5, $58-62$.

30. Churchill, R.C., Jr.; Ruehle, J.L. Occurrence, parasitism, and pathogenicity of nematodes associated with sycamore (Platanus occidentalis L.). J. Nematol. 1971, 3, 189-196. [PubMed]

31. Maleita, C.M.; Simões, M.J.; Egas, C.; Curtis, R.H.C.; Abrantes, I.M.d.O. Biometrical, biochemical, and molecular diagnosis of Portuguese Meloidogyne hispanica isolates. Plant Dis. 2012, 96, 865-874. [CrossRef] [PubMed]

32. Lima-Medina, I.; Somavilla, L.; Carneiro, R.M.D.G.; Gomes, C.B. Espécies de Meloidogyne em figueira (Ficus carica) e em plantas infestantes. Nematropica 2013, 43, 56-62.

33. Hunt, J. List of Intercepted Plant Pests; Bureau of Entomology and Plant Quarantine, United States Department of Agriculture: Washington, DC, USA, 1956.

34. Santos, M.S.N.d.A. Identificação de populações portuguesas de Meloidogyne spp. pelas reações induzidas em plantas diferenciadoras-I. In I Congresso Português de Fitiatria e Fitofarmacologia II; Instituto Superior de Agronomia: Lisboa, Portugal, 1980; pp. 147-150.

35. Santos, M.S.N.d.A.; Abrantes, I.M.d.O. Root-knot nematodes in Portugal. In Proceedings of the Second Research Planning Conference on Root-Knot Nematodes, Meloidogyne spp., Region VII. Athens, Greece, 22-26 March 1982; North Carolina State University Graphics: Raleigh, NC, USA, 1982; pp. 17-23.

36. Reis, L.G.L. Prospeção Nematológica. Relatório das atividades da Estação Agronómica Nacional: Oeiras, Portugal, 1983.

37. Santos, M.S.N.d.A.; Abrantes, I.M.d.O.; Fernandes, M.F.M. Identificação de populações portuguesas de Meloidogyne spp. (Nematoda: Meloidogynidae) pelas reações induzidas em plantas diferenciadoras-III. Ciênc. Biol. Ecol. Syst. (Portugal) 1987, 7, 37-42.

38. da Conceição, I.L.P.M.; da Cunha, M.J.M.; Feio, G.; Correia, M.; Vieira dos Santos, M.C.; Abrantes, I.M.d.O.; Santos, M.S.N.d.A. Root-knot nematodes, Meloidogyne spp., on potato in Portugal. Nematology 2009, 11, 311-313.

39. Esteves, I.; Maleita, C.; Abrantes, I. Root-lesion and root-knot nematodes parasitizing potato. Eur. J. Plant Pathol. 2015, 141, 397-406. [CrossRef]

40. Rusinque, L.; Inácio, M.L.; Mota, M.; Nóbrega, F. Morphological, biochemical and molecular characterisation of Meloidogyne javanica, from North Portugal, in tomato. Rev. Ciênc. Agrár. 2018, 41, 201-210. [CrossRef]

41. Fortuner, R.; Merny, G.; Roux, C. Morphometrical variability in Helicotylenchus Steiner, 1945. 3: Observations on African populations of Helicotylenchus dihystera and considerations on related species. Rev. Nématol. 1981, 4, 235-260.

42. Benson, D.M.; Barker, K.R.; Aycock, R. Effects of density of Helicotylenchus dihystera and Pratylenchus vulnus on American Boxwood growing in microplots. J. Nematol. 1976, 8, 322-326. [PubMed]

43. Willers, P.; Grech, N.M. Pathogenicity of the spiral nematode Helicotylenchus dihystera to Guava. Plant Dis. 1986, 70, 352. [CrossRef] 
44. Pedersen, J.F.; Rodriguez-Kabana, R. Nematode response to cool season annual graminaceous species and cultivars. Ann. Nematol. 1987, 1, 116-118.

45. Siddiqi, M.R. Helicotylenchus dihystera. C.I.H. Descriptions of Plant-Parasitic Nematodes. Set 1-9; Commonwealth Agricultural Bureaux: Farnham Royal, UK, 1972.

46. CABI/EPPO. Helicotylenchus dihystera. Distribution map. In Distribution Maps of Plant Diseases, 1st ed.; CABI Publishing: Wallingford, UK, 2010.

47. Plantwise Knowledge Bank. Common Spiral Nematode Helicotylenchus Dihystera; CABI Publishing: Wallingford, UK, 1956. Available online: https://www.plantwise.org/knowledgebank/datasheet/26824 (accessed on 30 March 2020).

48. Macara, A.M. Contribuição para o estudo de algumas espécies do género Heterodera Schmidt 1871 encontradas em Portugal-Relatório Final do Curso de Engenheiro Agrónomo; Instituto Superior de Agronomia, Universidade de Lisboa: Lisboa, Portugal, 1962.

49. Sher, S.A. Revision of the Hoplolaiminae (Nematoda) VI Helicotylenchus Steiner, 1945. Nematologica 1966, 12, 1-56. [CrossRef]

50. Siddiqi, M.R. On the genus Helicotylenchus Steiner, 1945 (Nematoda: Tylenchida), with descriptions of nine new species. Nematologica 1972, 18, 74-91. [CrossRef]

51. Coyne, D.L.; Fourie, H.H.; Moens, M. Current and future management strategies in resource-poor farming. In Root-Knot Nematodes; Perry, R.N., Moens, M., Starr, J.L., Eds.; CABI Publishing: Wallingford, UK, 2009; pp. 444-475.

52. Nicol, J.M.; Turner, S.J.; Coyne, D.L.; den Nijs, L.; Hockland, S.; Tahna Maafi, Z. Current nematode threats to world agriculture. In Genomics and Molecular Genetics of Plant-Nematode Interactions; Jones, J., Gheysen, G., Fenoll, C., Eds.; Springer: Berlin/Heidelberg, Germany, 2011; pp. 21-44.

53. Byrd, D.W.; Kirkpatrick, T.; Barker, K.R. An improved technique for clearing and staining plant tissues for detection of nematodes. J. Nematol. 1983, 15, 142-143.

54. Whitehead, A.G.; Hemming, J.R. A comparison of some quantitative methods of extracting small vermiform nematodes from soil. Ann. Appl. Biol. 1965, 55, 25-38. [CrossRef]

55. Pais, C.S.; Abrantes, I.M.d.O. Esterase and malate dehydrogenase phenotypes in Portuguese populations of Meloidogyne species. J. Nematol. 1989, 21, 342-346.

56. Zijlstra, C.; Donkers-Venne, D.T.H.M.; Fargette, M. Identification of Meloidogyne incognita, M. javanica and M. arenaria using sequence characterised amplified region (SCAR) based PCR assays. Nematology 2000, 2, 847-853. [CrossRef]

57. De Leij, O.; Félix, M.A.; Frisse, L.; Nadler, S.; Sternberg, P.; Thomas, W. Molecular and morphological characterisation of two reproductively isolated species with mirror image anatomy (Nematoda: Cephalobidae). Nematology 1999, 1, 591-612.

58. Hall, T.A. BioEdit: A user friendly biological sequence alignment editor and analyses program for windows 95/98/NT. Nucleic Acids Symp. Ser. 1999, 41, 95-98.

59. Kumar, S.; Stecher, G.; Tamura, K. MEGA7: Molecular evolutionary genetics analysis version 7. 0 for bigger datasets. Mol. Biol. Evol. 2016, 33, 1870-1874. [CrossRef] [PubMed]

(C) 2020 by the authors. Licensee MDPI, Basel, Switzerland. This article is an open access article distributed under the terms and conditions of the Creative Commons Attribution (CC BY) license (http://creativecommons.org/licenses/by/4.0/). 